\title{
Economic Growth and Monetary Policy Transmission Mechanism: An Empirical Assessment of Nigeria
}

\author{
Nnamdi Chinwendu, Nwaeze, Ph.D \\ Department of Economics, Abia State University Uturu, Nigeria
}

\begin{abstract}
This work investigates the monetary policy transmission mechanisms and their efficacy in predicting economic growth in Nigeria using the ARDL methodology. Variables included in the model were growth rate of real domestic gross product (RGDP), M2 broad money supply definition, cash reserve ratio (CRR), nominal exchange rate (EXCR); inflation rate (INFL), interest rate and deposit money banks credit to the private sector (BCR). The unit root test using the ADF test revealed that all our variables were integrated at levels I (0). The study proceeded to estimate the ARDL bounds tests; the ARDL long run estimations; the diagnostic tests, normality and stability tests respectively. The critical findings from our result and analysis revealed that broad money supply (M2), exchange rate (EXCR), cash reserve ratio (CRR) and the rate of inflation (INFL) were the major monetary policy transmission mechanism predicting the level of economic growth in Nigeria. Likewise, the study identified interest rate (INTR) and deposit money banks credit to the private sector (BCR) as weak transmission variables driving economic growth and prices in Nigeria. The study concludes that the monetary policy transmission mechanisms have had a mixed bag in predicting economic growth in Nigeria. This conclusion was arrived based on the fact that the findings suggest that the negative impacts outweigh the positives, especially, as the critical variables like interest rate, credit to the private sectors and exchange rate depreciation plays a key role in driving economic growth. The monetary authority should be religious in seeing through monetary policies, especially, in maintaining consistency. Devaluation or depreciation of the naira also is not pro-growth in Nigeria and should be jettisoned, pending the diversification of our economy and improvements in our domestic productive capacities. Evidently, access to private sector credit at a lower interest should be pursued vigorously.
\end{abstract}

Keywords: monetary policy, transmission mechanism, economic growth and devaluation

DOI: $10.7176 /$ RJFA/10-18-06

Publication date:September $30^{\text {th }} 2019$

\section{Introduction}

The broad objectives that drives monetary authorities in promulgating policies are encapsulated in achieving some macroeconomic desirables such as; economic growth, relative price stability and exchange rate stability among others. However, scholars, policy makers and monetary authorities alike differ as the best monetary policy transmission mechanism to achieve the set goals. This is so because empirical evidences have shown that the instruments of monetary policy have differing efficacies both in the short and long terms. This was the bias of Adeleke, Oboh and Shobande (2015) who admitted that monetary policy can serve as a growth stimulant through the creation of enabling environment where proper encouragement is provided to innovative entrepreneurs in order to bring about inclusive growth.

Borrowing from the above therefore, it is evident that changes in monetary policy, subject to the transmission channels used, tend to influence aggregate demand, growth, exchange rate and inflation, hence, stimulates employment in the process. This is in line with the statutory role of the Central Bank of Nigeria (CBN) as contained in the CBN act of 1959 as amended in several Decrees and consolidated in Decree 24 and 25 of 1991. In essence, monetary policy objectives of price stability, balance of payment equilibrium, promotion of employment and output growth and development and sustenance of sound financial system are the core mandate of the monetary authorities. Whereas there exists consensus on these broad objectives, there are discordance in terms of instruments or channels of achieving these objectives (Nwaeze and Onyekwere, 2018).

In all of these, the efficacy of monetary policy transmission mechanism is key to achieving the desired macroeconomic goals. According to Mengesha and Holmes (2013) and Nenbee and Krama (2017), monetary policy ought to be useful in developing countries just as they are useful in developed economies. Although the procedures for implementing monetary policy instruments differ from country to country, subject to the socioeconomic and political settings, there are some universal standards which some economies can rely on.

In essence, despite of the disparities in implementing monetary policy by countries, the broad objective remains the same. In line with this submission, the CBN (2011) defined monetary policy as the specific actions taken by the Central Bank-Monetary Authority- to regulate the value, supply and cost of money in the economy, aimed at achieving programmed macroeconomic objectives. Along this thought, the CBN (2015) added that monetary policy is intended to control money supply through the operation of monetary aggregates that are in consonant with the level and structure of interest rates, and other variables that determine or affect domestic credit 
availability.

Traditionally, as observed by Nwaeze and Onyekwere (2018) the focus of the monetary policy of the CBN in Nigeria, has its focus chiefly on the maintenance of price stability while the promotion of growth and employment have inadvertently become secondary goals of monetary policy in Nigeria. In essence, the monetary policy has played prominent role and has proven to be most viable instrument for achieving medium term stabilization objectives in the Nigerian economy. For instance, during the global recession of 2008 and the recession which occurred in Nigeria from the twilight of 2015 and early 2017, the CBN maintained a higher interest rate regime, which was orchestrated by a sustained double digit MPR (Monetary Policy Rates) of between 13.5 percent and 14.5 percent. This suggests that the $\mathrm{CBN}$ was more concerned in reducing inflation rate, which rose as high as 17 percent, than stimulating growth through reduction of cost of fund (interest rate), as this could have encouraged borrowing and investment domestically by entrepreneurs.

Consequently, the Nigerian economy has experienced a roller coaster economic performance over the years. This has been the case despite attempts by the monetary authority to utilize monetary policy channels to stabilize the economy and launch it on the part of sustainable economic growth; given that price stability in terms of tolerable inflation rate, interest rate and stable exchange rate are catalyst to economic growth.

Borrowing from the foregoing narratives, the primary aim of this study is to investigate the monetary policy transmission instruments available to the Central Bank of Nigeria $(\mathrm{CBN})$ that is most effective in stimulating and sustaining economic growth.

\section{Literature Review}

Monetary policy entails the adjustment of the monetary stock through various channels including but not limited to, open market operation (OMO), availability of credit to the economy, reserve requirement, interest and exchange rate management, as well as the expectations to influence the level of economic activities and inflation in a predetermined direction. The efficacy of these instrument to moderate and stimulate economic activities has been central to scholarly postulations and debates. In fact, the transmission channel of monetary policy and its efficacy to stimulate investment, output and employment is central to the Keynesian-Monetarist controversies.

To the Keynesians, the basic determinant of real output, employment and the price level is the level of aggregate expenditure, which its basic equation is GDP $=\mathrm{C}+\mathrm{I}+\mathrm{G}+(\mathrm{X}-\mathrm{M})$. These components of aggregate expenditure are determined by a wide variety of variables, for the most part are unrelated to the supply of money. To this, the Keynesians argue that monetary policy entails a lengthy transmission mechanism, involving monetary policy decisions, bank reserves, the interest rate, investment and finally nominal GDP. Uncertainties at each step in the mechanism limit the effectiveness and dependability of monetary policy unlike fiscal policy. Specifically, combination of a relatively flat demand for money curve and a relatively steep investment-demand curve makes monetary policy ineffective.

The Classists and the Monetarists would not buy into any of these Keynesian argument. Instead, Monetarism focuses on the equation of exchange; $\mathrm{MV}=\mathrm{PQ}$. To them because velocity is basically stable, the critical determinant of the price level is the supply of money. They argue that fiscal policy is also weak and uncertain in its effects. To remedy, increased spending must be finance by an increase in money supply, otherwise, deficit spending will raise the interest rate and crowd out private investment spending. Therefore, the monetarists believe that the relative stability of velocity of money indicates a rather dependable link between money supply and nominal GDP. However, because of a variable time lags in becoming effective and the inappropriate use of the interest rate as a guide to policy, the application of discretionary monetary policy to fine-tune the economy is likely to fail, as such policy in practice has tended to destabilize the economy. As a form of prescription, it is recommended for a monetary rule by the monetary authority whereby the money supply is increased in accordance with the long term growth of real GDP. (Fisher, 1911; Keynes, 1936; Freidman, 1956; Odozi, 2008; Nwaeze and Onyekwere, 2018).

Summarily, both Keynesians and the Monetarists are helpful in understanding macroeconomic dynamics. Although both had differing views in terms of approach, their approaches can be easily reconciled. Thus, the Keynesian equation can be readily translated into monetarist terms. In the monetarist approach, total spending is the supply of money multiplied by its velocity. In essence, $\mathrm{MV}$ is the monetarist counterpart equilibrium $\mathrm{C}+\mathrm{I}+\mathrm{G}$ $+(\mathrm{X}-\mathrm{M})$. Given that MV is the total amount spent on final goods in one year, it is equal to nominal GDP. Furthermore, nominal GDP is the sum of the physical outputs of goods and services (Q) multiplied by their respective prices $(\mathrm{P})$. Thus, GDP $=\mathrm{PQ}$. The only major controversy is in the transmission mechanism of monetary policy to influencing investment, output and employment. While the Keynesians believes that monetary policy entails a lengthy and indirect transmission, the monetarist think the transmission is direct and short.

The above debate has elicited further studies as to the efficacy of monetary policy transmission mechanisms to stimulate investment, output and employment. The study of Mengesha and Holmes (2013) studied the best practices of monetary policy implementation in the Eritrean economy. The study employed quarterly data from Q1 1996 - Q4 2008, using the Vector Autoregressive technique. Their conclusion was that interest rate and official 
exchange rate channels are imperious amongst other transmission channels. However, effective exchange rate and credit channels exist through the black foreign exchange market and credit issued to the government sector. In terms of recommendation, the Bank or Eritrea should deploy and manipulate the reserve required ratio in controlling inflation. Nenbee and Krama (2017) investigated the transmission mechanism of monetary policy in Nigeria. Variables included in their model were; RGDP, inflation rate, exchange rate and interest rate, among others. The result of their analysis reveal that the major monetary policy transmission channels are credit, interest rate and exchange rate channels, while asset price channel had a weak case in Nigeria. Their conclusion and recommendation is that the monetary authority needs to strengthen and enforce the various prudential guidelines regarding growth in money supply and interest rate that would fast-track the pace of financial intermediation process in Nigeria.

Onyeiwu (2012) examined the impact of monetary policy on the performance of the Nigerian economy using the Ordinary Least Square method. The result show that monetary policy represented by money supply ex ert a positive impact on GDP growth and balance of payments (BOPs) but negative impact on rate of inflation. His conclusion was that monetary policy is effective in regulating liquidity of the economy, hence, affect some macroeconomic variables such as output, prices and employment. Okwo, et al (2012) studied the effect of monetary policy outcome on macroeconomic stability in Nigeria. The study analyzed gross domestic product, credit to the private sector, net credit to the government and inflation, using the OLS technique. His findings show that none of the variables were significant, which suggested that monetary policy as a policy option may not be active in influencing macroeconomic stability.

\section{Methods of Study}

In order to achieve the objectives of this study, the variables included in this study were; real gross domestic product (RGDP), broad money supply $\left(\mathrm{MS}_{2}\right)$, and cash reserve ratio (CRR), exchange rate of the US dollar to the Naira (EXR), inflation rate (INF), and interest rate (INT) and banking sector credit to the private sector (BCR). The data for these variables were sourced from the Central bank of Nigeria statistical bulletin, for various years.

After describing the data using mean, minimum, maximum, standard deviation and kurtosis, the stationarity test was conducted using the Augmented Dickey Fuller (ADF) to determine the unit roots characteristics of the variables in the model. The level of integration of the residual error term of a set of non-stationary time series aggregate should be zero (i.e Ut 1(0)) in order to qualify as an error correction model. The analysis was concluded with test for autocorrelation, autoregressive, normality and heteroskedasticity (sensitivity analysis).

The Autoregressive Distributed lags (ARDL) Bound Testing procedure. The results of the unit roots tests indicate that all our variables including the dependent variable, RGDP, were stationary at levels; thus, I (0)). This shows evidence that the residual error terms are Ut $\sim 1(0)$. The autoregressive distributed lag (ARDL) bounds testing procedure introduced by Pesaran and Pesaran (1997), Pesaran and Shin (1999), and Pesaran et al (2001) is preferred in testing for longrun relationships or cointegration. This technique is advantageous because it yields valid results regardless of whether the underlying variables are $i(1)$ or $i(0)$, or a combination of both. The autoregressive distributed lag (ARDL) model used in this study is:

$\mathrm{RGDP}=\mathrm{f}(\mathrm{M} 2, \mathrm{CRR}, \mathrm{EXCR}, \mathrm{INFL}, \mathrm{INTR}, \mathrm{BCR})$

In the process of estimation, parameters and a random term "U" are introduced into the model to capture variables not included in the model but influenced economic growth. Hence, equation 1 above could be stated thus:

$$
\mathrm{RGDP}_{\mathrm{t}}=\alpha \mathrm{o}+\alpha 1 \mathrm{M} 2+\alpha 2 \mathrm{CRR}+\alpha 3 \mathrm{EXCR}+\alpha 4 \mathrm{INFL}+\alpha 5 \mathrm{INTR}+\alpha 6 \mathrm{BCR}+\mathrm{U}_{\mathrm{t}}
$$

In order to estimate the above model using ARDL technique, equation (2) could be transformed into a log linear form by taking the natural log of the variables as follows:

$\mathrm{RGDP}_{\mathrm{t}}=\alpha \mathrm{o}+\alpha 1 \operatorname{lnM} 2+\alpha 2 \operatorname{lnCRR}+\alpha 3 \operatorname{lnEXCR}+\alpha 4 \operatorname{lnINFL}+\alpha 5 \ln I N T R+\alpha 6 \ln \mathrm{BCR}+\varepsilon_{\mathrm{t}} \ldots \ldots \ldots \ldots \ldots . . . . . . .$.

Where:

RGDP $=$ Real Gross Domestic Product

MS2 = Broad Money Supply

$\mathrm{CRR}=$ Cash Reserve Ratio

$\mathrm{EXR}=$ Exchange Rate of the naira to the US Dollar

$\mathrm{INF}=$ Inflation Rate

$\mathrm{INT}=$ Interest Rate

$\mathrm{BCR}=$ Banking Sector Credit to the Private Sector

$\mathrm{Ln}=$ Natural logarithm,

$\mathrm{U}=$ stochastic term

$\alpha 1, \alpha 2, \alpha 3, \alpha 4$, and $\alpha 5$ are elasticities of money supply, cash reserve ratio, exchange rate, inflation rate, interest rate and banking sector credit to the private sector in Nigeria.

Apriori expectation is that $\alpha 1<0, \alpha 2<0, \alpha 3<0, \alpha 4<0, \alpha 5<0$ and $\alpha 6>0$

The implementation of the ARDL test for Eq. (1) involves the estimation of the following models: 


$$
\begin{aligned}
& \Delta l n R G D P_{\mathrm{t}}=a_{0}+\sum_{i=1}^{n} a_{1} \Delta \ln R G D P_{\mathrm{t}-\mathrm{i}}+\sum_{i=0}^{n} a_{2} \Delta \ln M 2_{\mathrm{t}-\mathrm{i}}+\sum_{i=0}^{n} a_{3} \Delta \ln C R R_{\mathrm{t}-\mathrm{i}}+\sum_{i=0}^{n} a_{4} \Delta \ln E X C R_{\mathrm{t}-\mathrm{i}} \\
& +\sum_{i=0}^{n} a_{5} \Delta \ln I N F L_{t-i}
\end{aligned}
$$

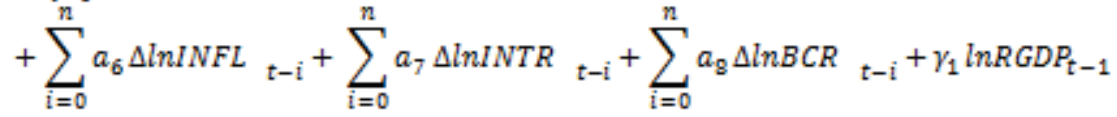

$$
\begin{aligned}
& +\gamma_{2} \ln M 2_{\mathrm{t}-1}+\gamma_{3} \operatorname{lnCRR}_{\mathrm{t}-1}+\gamma_{4} \ln E X C R_{\mathrm{t}-1}+\gamma_{5} \ln I N F L_{\mathrm{t}-1}+\gamma_{6} \ln I N T R_{\mathrm{t}-1}+\gamma_{7} \ln B C R_{\mathrm{t}-1} \\
& +\varepsilon_{t}
\end{aligned}
$$

The following hypotheses are tested to investigate the existence of co-integration among the variables: the null hypothesis of no cointegration among the variables in Eq. (4) is $\left(H_{0}: a_{1}=a_{2}=a_{3}=a_{4}=a_{5}=a_{6}=0\right.$ ) against the alternative hypothesis $\left(H_{1}: a_{1} \neq a_{2} \neq a_{3} \neq a_{4} \neq a_{5} \neq a_{6} \neq 0\right)$. The decision to reject or accept $H_{o}$ (no co-integration among the variables) is based on the following conditions: if the calculated F-statistics is greater than the upper critical bound, then $H_{o}$ is rejected and the variables are co-integrated, if the calculated F-statistics is less than the lower bound, then $H_{o}$ is accepted and the variables are not co-integrated, but if the calculated Fstatistics remains between the lower and upper critical bounds then the decision is inconclusive (Pesaran et al., 2001). For the parameter $\gamma_{i}, i=1,2,3,4,5$ and 6 are the corresponding long-run multipliers, whereas, for the parameter $\alpha_{\mathrm{i}}, \mathrm{i}=1,2,3,4,5$ and 6 are coefficients of the short-run dynamic of the ARDL model. $\varepsilon_{\mathrm{t}}$ is serially uncorrelated stochastic term with zero mean and constant variance, and $\Delta$ is the first difference operator.

After testing for cointegration among the variables, the long-run coefficients of the variables are then estimated. The existence of cointegration between the variables implies that causality exist in at least one direction. This study uses Akaike Information Criterion (AIC) for selecting the optimal lag length. The error correction model for the estimation of the short run relationships is specified as:

$$
\begin{aligned}
\Delta l n R G D P_{\mathrm{t}}=a_{0}+ & \sum_{i=1}^{n} a_{1 i} \Delta \ln R G D P_{\mathrm{t}-\mathrm{i}}+\sum_{i=0}^{n} a_{2 i} \Delta \ln M 2_{1_{\mathrm{t}-\mathrm{i}}}+\sum_{i=0}^{n} a_{3 i} \Delta \ln C R R_{2 \mathrm{t}-\mathrm{i}}+\sum_{i=0}^{n} a_{4 i} \Delta \ln E X C R_{3 \mathrm{t}-\mathrm{i}} \\
& +\sum_{i=0}^{n} a_{5 i} \Delta \ln I N F L_{4 t-i}+\sum_{i=0}^{n} a_{6 i} \Delta \ln I N T R_{5 t-i}+\sum_{i=0}^{n} a_{7 i} \Delta \ln B C R_{6 \mathrm{t}-\mathrm{i}}+\lambda_{2} E C M_{\mathrm{t}-1}+u_{2 \mathrm{t}}
\end{aligned}
$$

$E C M_{t-1}$ is the error correction term obtained from the cointegration model. The error correction coefficients $\left(\lambda_{1}\right.$ and $\left.\lambda_{2}\right)$ indicate the rate at which the cointegration models correct previous period disequilibrium or speed of adjustment to restore the long-run equilibrium relationship. A negative and significant $E C M_{t-1}$ coefficient implies that any short term movement between the dependent and explanatory variables will converge back to the long-run relationship.

Finally, the following diagnostic tests are conducted to ensure the acceptability of the empirical models: Breusch-Godfrey serial correlation LM test, ARCH test for heteroscedasticity, Jarque-Bera normality test and Ramsey RESET test for functional form. The stability of the long-run coefficients together with the short-run dynamics are tested using the cumulative sum of recursive residuals (CUSUM) and the cumulative sum of squares of recursive residuals (CUSUMSQ) tests. If the plot of CUSUM and CUSUMSQ statistics stays within the 5\% range of the significance level, then all the coefficients in the error correction model are assumed to be stable, but if the plot of CUSUM and CUSUMSQ statistics crossed the 5\% range of the significance level, the coefficients in the error correction model are considered unstable (Bekhet and Matar, 2013). 


\section{Empirical Result}

4.1 Descriptive Statistics.

Table 1: Descriptive Statistics Result

\begin{tabular}{|lcllllll|}
\hline & RGDP & LOG(M2) & CRR & LOG(EXCR) & INFL & INTR & BCR \\
Mean & 3.843684 & 6.663963 & 38.00263 & 3.421892 & 19.32450 & 17.73947 & 14.96603 \\
Median & 4.130000 & 6.746935 & 44.65000 & 4.577607 & 12.54700 & 17.56500 & 13.47650 \\
Maximum & 14.60000 & 10.32164 & 64.10000 & 5.732985 & 72.83600 & 31.65000 & 38.38700 \\
Minimum & -13.10000 & 2.785011 & 1.000000 & -0.494296 & 5.382000 & 8.920000 & 8.710000 \\
Std. Dev. & 5.157013 & 2.532758 & 17.91343 & 1.972647 & 17.25493 & 4.836682 & 5.954166 \\
Skewness & -0.868394 & -0.083194 & -0.753329 & -0.764014 & 1.742219 & 0.222502 & 2.531775 \\
Kurtosis & 4.890380 & 1.603027 & 2.326502 & 2.280085 & 4.837219 & 3.710387 & 9.799506 \\
Jarque-Bera & 10.43411 & 3.133761 & 4.312394 & 4.517487 & 24.56807 & 1.112572 & 113.7986 \\
Probability & 0.005423 & 0.208695 & 0.115765 & 0.104482 & 0.000005 & 0.573334 & 0.000000 \\
Sum & & & & & & & \\
Sum Sq. Dev. & 984.0071 & 237.3500 & 11872.97 & 143.9795 & 11016.10 & 865.5592 & 1311.728 \\
Observations & 38 & 38 & 38 & 38 & & & 38 \\
\hline
\end{tabular}

Source: Author's computation using E-views 10.0

As captured in table 1 above, the growth rate of real gross domestic product (RGDP) averaged at 3.84 percent between 1981-2018, with a corresponding maximum value of 14.6 and a minimum value of -13.1 . The mean value of M2 definition of money supply was 6.66 with a peak of 10.32 and a lowest value of 2.7. In terms of volatility, the cash reserve ratio (CRR) with a standard deviation value of 17.91 was the most volatile variable, followed closely by the rate of inflation with a standard deviation of 17.25. In like manner, the exchange rate was the least volatile variable with a value of 1.97 throughout the period under investigation. The skewness statistic showed that only INFL and INTR were positively skewed, while the other three four variables namely, RGDP, M2, CRR and EXCR were all negatively skewed. While the positive values indicated right tailed, the negative values showed left tail of the normal distribution. The kurtosis statistic showed also that RGDP and INFL had large tails (leptokurtic) suggesting that its distributions were peaked relative to normal distribution. On the other hand, all other variables, namely, M2, EXCR, CRR and INTR had thin tails (platykurtic), suggesting that its distributions were flat relative to normal distribution.as peaked. Based on these observations, it is evident that the series are non-stationary, which is not surprising since it involves time series data. The presence of unit root (non- stationarity) is equally supported by the Jarque Bera statistic. For instance, JB value for RGDP and INFL of 10.43 and 24.57 respectively are above 5.99 value or $5 \%$ critical value, hence both null hypotheses of a normal distribution are rejected. However, the null hypotheses of the other remaining variables cannot be rejected based on their probability values.

\subsection{Unit Root Test}

Our descriptive statistics have been able to guide us to the fat that the time series under investigation is nonstationary, hence the need to conduct a unit root test, using the Augmented Dickey-Fuller test to achieve stationarity of our model. The result of the ADF test is presented in table 2 below.

Table 2. ADF Unit Root Test Result.

\begin{tabular}{|l|l|l|l|l|}
\hline Variables & $\begin{array}{l}\text { ADF Statistic @ } \\
\text { Levels }\end{array}$ & $\begin{array}{l}\text { ADF Critical } \\
\text { Value }\end{array}$ & $\begin{array}{l}\text { Level of } \\
\text { Significance }\end{array}$ & $\begin{array}{l}\text { Order of } \\
\text { Integration }\end{array}$ \\
\hline RGDP & $-4.509869^{*}$ & -2.943427 & $5 \%$ & $\mathrm{I}(0)$ \\
\hline M2 & $-3.851154^{*}$ & -2.945842 & $5 \%$ & $\mathrm{I}(0)$ \\
\hline CRR & $-5.709913^{*}$ & -2.945842 & $5 \%$ & $\mathrm{I}(0)$ \\
\hline EXCR & $-5.166283^{*}$ & -2.945842 & $5 \%$ & $\mathrm{I}(0)$ \\
\hline INFL & $-3.470100^{*}$ & -2.945842 & $5 \%$ & $\mathrm{I}(0)$ \\
\hline INTR & $-6.734444^{*}$ & -2.945842 & $5 \%$ & $\mathrm{I}(0)$ \\
\hline BCR & $-5.468876^{*}$ & -2.945842 & $5 \%$ & $\mathrm{I}(0)$ \\
\hline
\end{tabular}

Source: Author's computation using e-view 10.0

Note: * indicates the order of integration at levels.

From table 2 above, all our variables were integrated at levels, denoting that they were all stationary (no presence of unit root). All variables are in their ordinary forms except EXCR and M2 that are in their logged transformation forms. From this result, we conclude that all our variables are stationary at levels or I (0). The implication is that our outcome would be valid for policy implementations. The uniqueness in the order of stability in the variables necessitate the use of ARDL in the estimation of the long run relationship among the variables and the error correction model. 


\section{3: ARDL Bounds Test}

Table 3. ARDL Bounds Test

Null Hypothesis: No long run relationship exists

\begin{tabular}{|l|l|l|l|}
\hline Test Statistic & \multicolumn{1}{|l|}{ Value } & \multicolumn{1}{l|}{ k } \\
\hline F- Statistic & 9.783435 & 6 \\
\hline Critical Value Bounds & \multicolumn{2}{|l|}{} \\
\hline Significance & $\mathrm{I}(0)$ Bounds & $\mathrm{I}(1)$ Bounds & 2.94 \\
\hline $10 \%$ & & 2.27 & 3.28 \\
\hline $5 \%$ & 2.55 & 3.61 \\
\hline $2.5 \%$ & & 2.88 & 3.99 \\
\hline $1 \%$ & & & \\
\hline
\end{tabular}

Table 3 displays the calculated F- statistics (F-statistic $=9.783435)$, showing that the null hypothesis of no long run relationship is rejected at all critical levels (i.e. 10, 5, $2.5 \& 1$ percent). We arrived at this conclusion because the estimated bound test (F-calculated) is higher than the upper bound critical value of 4.68 as tabulated in Pesaran et al (2001). This result establishes the existence of a long run relationship or cointegration between economic growth and monetary policy transmission mechanism in Nigeria. Having established the long-run or cointegration relationship in our investigation, we now proceed to estimate the long run coefficients by estimating an ARDL of the order 1, 0, 0, 3, 3, 1, 0 .

Table 4: Estimated Long-Run Coefficients of the ARDL $(1,0,0,3,3,1,0)$

\begin{tabular}{|c|c|c|c|c|}
\hline \multicolumn{5}{|c|}{ Long run coefficients } \\
\hline Variable & Coefficient & Std. Error & t-statistic & Probability \\
\hline LOG(M2) & -7.743154 & 1.084134 & -7.142247 & 0.0000 \\
\hline CRR & -0.155934 & 0.035530 & -4.388772 & 0.0003 \\
\hline LOG(EXCR) & 8.978434 & 1.372071 & 6.543712 & 0.0000 \\
\hline INFL & -0.199282 & 0.037787 & -5.273850 & 0.0000 \\
\hline INTR & -0.200774 & 0.157624 & -1.273757 & 0.2174 \\
\hline BCR & -0.028681 & 0.061491 & -0.466417 & 0.6460 \\
\hline $\mathrm{C}$ & 43.20442 & 6.000134 & 7.200576 & 0.0000 \\
\hline \multicolumn{5}{|c|}{$\mathrm{R}^{2}=0.83 ; \mathrm{R}^{2}$ adjusted $=0.74 ; \mathrm{F}-$ statistic $=7.99(0.00021)$ Durbin Watson $=2.3$} \\
\hline $\begin{array}{l}\text { CointEq = RGDP } \\
.2008 * \text { INTR }-0.0\end{array}$ & $\begin{array}{l}32 * \text { LOG(M2) } \\
\text { CR + 43.2044 }\end{array}$ & $9 *$ CRR + 8.9784*LOC & \multicolumn{2}{|c|}{$-0.1993 *$ INFL - } \\
\hline
\end{tabular}

The long-run result estimated in table 4 indicates that the overall growth model is well fitted as the explanatory variables explained over 74 percent $\left(\mathrm{R}^{2}\right.$-adjusted) variation in economic growth. The result also shows that $\mathrm{M} 2$ definition of money supply exhibits negative and significant impact on economic growth. This implies that the M2 is a major monetary policy transmission mechanism driving the economy (RGDP) in Nigeria. This finding is in line with the findings of Nenbee and Krama (2017), and Onyeiwu (2012). Thus, the level of money supply in the economy and the ability of the monetary authority to control the growth of money, plays a pivotal role is deciding the faith of RGDP in Nigeria. This also conforms with theoretical and aprior expectations. The long-run coefficient of CRR is also negative and significant, conforming to theoretical expectations that increase in cash reserve ratio of deposit money banks in an economy will inhibit the capacities to create money and credit, hence hinder economic growth. This is true in the case of Nigeria as the CRR has hovered between 22-40 percent within the study period. Currently, in a bid to combat growth in money supply and inflation in Nigeria, the CRR is fixed at 22.5 percent. This rate has remained unchanged for a fairly long period as a monetary policy transmission tool of the CBN. On the other hand however, exchange rate shows a positive and significant relationship with RGDP. This is contrary to theory, as currency appreciation ought to retard economic growth while depreciation embers economic growth. The case of Nigeria, however, is a peculiar case as the depreciation of the naira over the study period has not impacted positively to the growth of the economy. This is not unconnected to the fact that Nigeria is a mono-product economy predominantly exporting crude oil as the only visible product in the international market, while she imports virtually all her domestic consumables including refined petroleum products. This findings is in line with that of Nteegah and Moses (2017).

As expected, inflation rate coefficient of the long-run ARDL estimation was negative and significant, implying that rising inflation in the economy negates the growth objective in the long run. It also indicates that inflation rate is a vital monetary policy transmission mechanism in Nigeria. This is also evident in Nigeria as high rate of inflation has coincided with worsening economic growth fortunes. Inflation erodes households' purchasing power and also serves as a disincentive to lending, as lenders would be the losers in the long-run. As a corollary, rising rate of inflation could fuel interest rate increase in order to offset the long term financial losses and erosion of monetary value. Interest rate (INTR) on the other though rightly (negative) signed was found to be insignificant as a monetary policy mechanism tool in predicting RGDP. The implication is that interest rate plays an 
insignificant role as a monetary policy tool, especially, in regulating economic growth. This is in line with the findings of Okwo et al (2012) where they discovered that the macroeconomic variables in Nigeria including interest rate had insignificant impact on economic growth. This findings, may not be unconnected with fiscal dominance in Nigeria and more credit to government at all levels at the expense of the real sectors of the economy. In like manner, deposit money bank credits to the private sector (BCR) was to have exhibited negative response to economic growth. This is against theoretical postulations that credits to the private sector stimulates economic growth. This peculiar situation in Nigeria is as a result of reluctance of deposit money bank in lending to the private sector. In sum, BCR is not a potent monetary policy transmission mechanism of predicting growth in Nigeria. This is in consonance with Nenbee and Onuchukwu (2017).

Having robustly analyzed the long-run coefficients of our estimation, we must conform to the Granger representation theory. According to the theory, when variables are cointegrated, there must also exist an error correction model (ECM) that demonstrates that short run dynamics of the cointegrated variables towards their equilibrium values. The result of the error correction model presented in table 5 below. From table 5, it shows that the error term is negative and significant. The error term coefficient of -0.828601 shows evidence of speedy adjustment towards long run equilibrium. Thus about 83 percent disequilibrium is corrected on yearly basis by changes in economic growth). This implies that if there is a shock, the long-run equilibrium will return to its steady state easily. The high of the coefficient of the error term also indicates that it will take very short time to restore the steady-state relation if the system is distorted. Also, from equation 6, both the short run and long run results yielded the same sign for the variables which signifies consistency in the effects of the independent variables on economic growth in Nigeria.

Table 5. Error Correction Estimates of the ADRL Model

\begin{tabular}{|c|c|c|c|c|}
\hline \multicolumn{5}{|c|}{ ARDL Error Correction Regression } \\
\hline \multicolumn{5}{|c|}{ Dependent Variable: D(RGDP) } \\
\hline \multicolumn{5}{|l|}{ Sample: 19812018} \\
\hline \multicolumn{5}{|c|}{ Included observations: 35} \\
\hline Variable & Coefficient & Std. Error & t-Statistic & Prob. \\
\hline RGDP(-1) & -1.082860 & 0.135678 & -7.981101 & 0.0000 \\
\hline LOG(M2) & -8.384748 & 1.507188 & -5.563174 & 0.0000 \\
\hline CRR & -0.168854 & 0.044328 & -3.809218 & 0.0011 \\
\hline LOG(EXCR(-1)) & 9.722382 & 1.884311 & 5.159647 & 0.0000 \\
\hline INFL(-1) & -0.215795 & 0.047212 & -4.570746 & 0.0002 \\
\hline $\operatorname{INTR}(-1)$ & -0.217410 & 0.168722 & -1.288569 & 0.2123 \\
\hline BCR & -0.031057 & 0.066918 & -0.464103 & 0.6476 \\
\hline DLOG(EXCR) & -2.442766 & 1.607917 & -1.519212 & 0.1444 \\
\hline DLOG(EXCR(-1)) & -8.892584 & 2.021646 & -4.398685 & 0.0003 \\
\hline DLOG(EXCR(-2)) & -4.944205 & 1.595089 & -3.099643 & 0.0056 \\
\hline $\mathrm{D}(\mathrm{INFL})$ & -0.068649 & 0.032249 & -2.128733 & 0.0459 \\
\hline D(INFL(-1)) & 0.127061 & 0.031962 & 3.975356 & 0.0007 \\
\hline D(INFL(-2)) & 0.127506 & 0.035673 & 3.574304 & 0.0019 \\
\hline D(INTR) & 0.241463 & 0.156557 & 1.542330 & 0.1387 \\
\hline $\operatorname{ECM}(-1)$ & -0.828601 & 0.105345 & -10.27916 & 0.0000 \\
\hline $\mathrm{C}$ & 46.78432 & 7.988487 & 5.856468 & 0.0000 \\
\hline R-squared & \multicolumn{2}{|c|}{0.870431 Mean dependent var } & \multicolumn{2}{|l|}{0.272000} \\
\hline Adjusted R-squared & 0.836839 & S.D. dependent var & \multicolumn{2}{|l|}{4.155948} \\
\hline S.E. of regression & 1.678723 & Akaike info criterion & \multicolumn{2}{|l|}{4.071575} \\
\hline Sum squared resid & $76.08895 \mathrm{~S}$ & Schwarz criterion & \multicolumn{2}{|l|}{4.427083} \\
\hline Log likelihood & $-63.25256 \quad \mathrm{H}$ & Hannan-Quinn criter. & \multicolumn{2}{|l|}{4.194296} \\
\hline Durbin-Watson stat & 2.318590 & & & \\
\hline
\end{tabular}




\subsection{Diagnostic Tests}

Table 6. Breusch-Godfrey Serial Correlation LM Test:

\begin{tabular}{llll}
\hline F-statistic & 1.301530 & Prob. F(2,18) & 0.2965 \\
Obs*R-squared & 4.422019 & Prob. Chi-Square(2) & 0.1096 \\
\hline
\end{tabular}

Table 7. Heteroskedasticity Test: ARCH

$\begin{array}{lllr}\text { F-statistic } & 0.019436 & \text { Prob. F(1,32) } & 0.8900 \\ \text { Obs*R-squared } & 0.020639 & \text { Prob. Chi-Square(1) } & 0.8858\end{array}$

\section{Source: Authors computation using E-views 10}

\section{Figure 1. Normality Test}

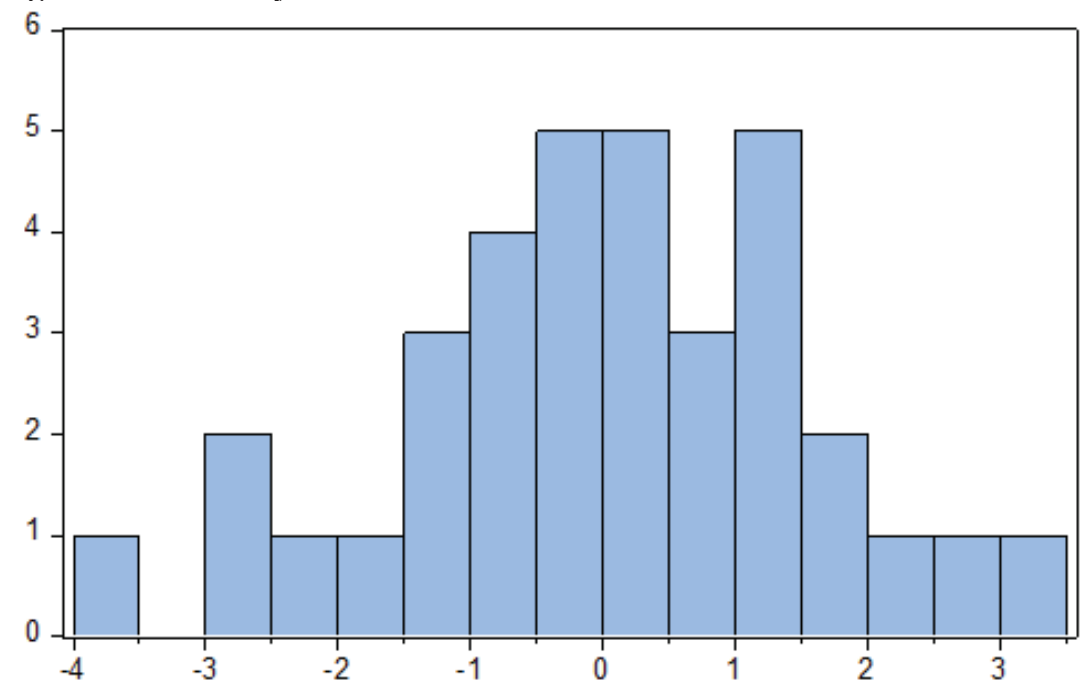

\begin{tabular}{lc|}
\hline \multicolumn{2}{l}{ Series: Residuals } \\
Sample 1984 2018 \\
Observations 35 \\
Mean & $-1.48 \mathrm{e}-15$ \\
Median & 0.041573 \\
Maximum & 3.011477 \\
Minimum & -3.610992 \\
Std. Dev. & 1.495965 \\
Skewness & -0.258058 \\
Kurtosis & 2.915289 \\
& \\
Jarque-Bera & 0.398929 \\
Probability & 0.819169 \\
\hline
\end{tabular}

Source: Authors computation using E-views 10

The empirical estimations for autocorrelation, autoregressive, normality and heteroskedasticity (sensitivity analysis) are reported above to test the following null hypotheses:

$\checkmark$ There is no serial correlation.

$\checkmark$ There is no functional form misspecification.

$\checkmark \quad$ There is no heteroscedasticity. Thus, our model is homoscedastic.

$\checkmark$ There is no non-normal error.

The results of the above tests show that the short-run model passed the diagnostic tests. The results revealed that there is no trace of autocorrelation at $5 \%$ level of significance and that the model passes the test for normality, there is also evidence to show that the error term is normally distributed. While the Jargue-Bera statistic was deployed to investigate whether the errors of the ARDL ECM were normally distributed, the ARCHAutoregressive Conditional Heteroscedasticity test was used to find out whether or not the variance of the residuals in the model was homoscedastic. Finally, Breusch-Godfrey Serial Correlation LM test was employed as a higher order test for serial correlation.

Figure 2 and 3. Stability Tests

In examining the stability of the coefficients of the independent variables in the ARDL model during the sample period, we deployed the CUSUM and CUSUM Square stability tests, as illustrated below in figure 2 . From the result, it shows that the parameters of the independent variables in the short-run and long-run dynamic model are stable over the study period, given that the graph laid between the dotted lines for both tests. As shown in the graphs, the recursive residuals and CUSUM lines stayed within the 5 percent critical bound. As depicted in figure 2 and 6 neither the recursive residual nor CUSUM plots across the 5 percent critical lines, hence these statistics prove the stability of the long-run coefficients of the regressors that have an effect on the economic growth in Nigeria. 
Figure 2 and 3: CUSUM SQ and CUSUM Tests

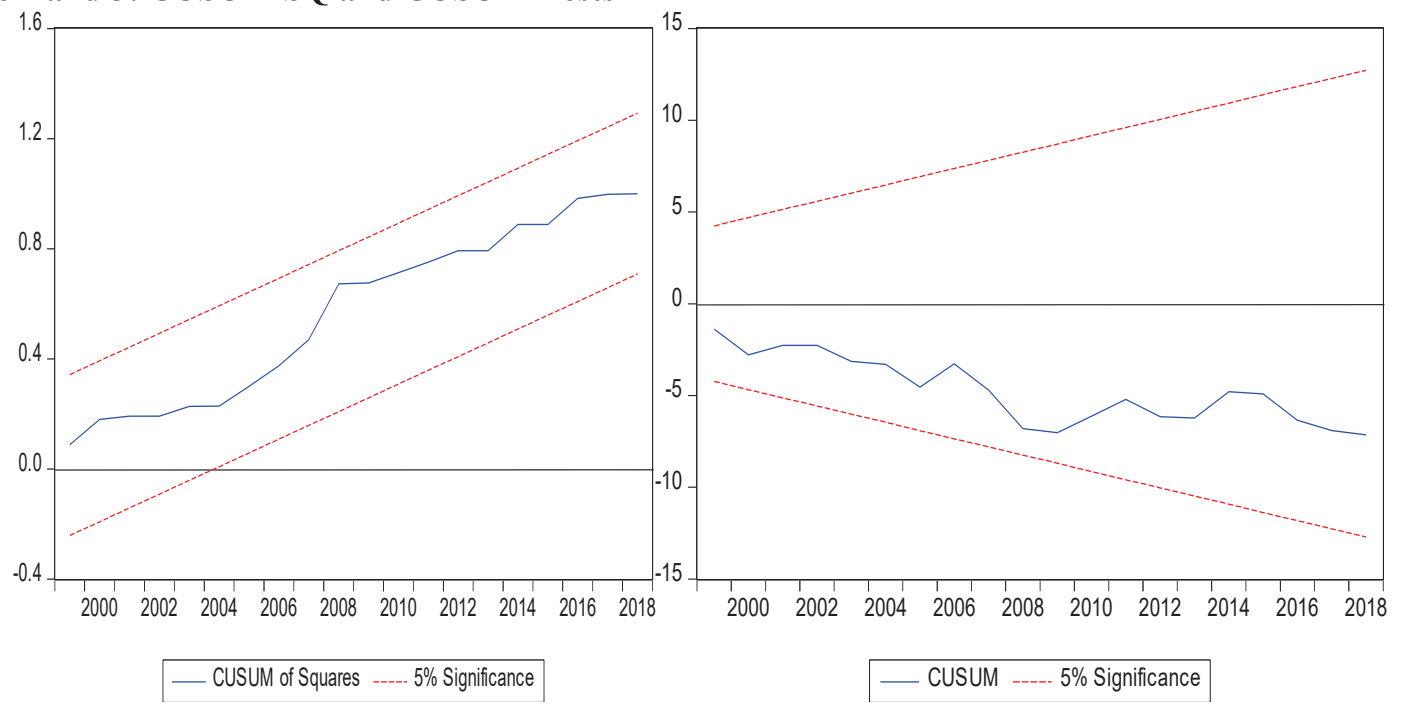

\section{Conclusion}

This work investigates the monetary policy transmission mechanisms and their efficacies in predicting economic growth (proxy by RGDP growth rate) in Nigeria using the Autoregressive Distributed Lag model (ARDL) methodology. Our empirical analysis began with the descriptive statistics; the usual unit root test, using the ADF test and we proceeded to estimate the ARDL bounds tests; the ARDL long run estimations; the diagnostic tests, normality and stability tests respectively. The critical findings from our result and analysis reveal that broad money supply (M2), exchange rate (EXCR), cash reserve ratio (CRR) and the rate of inflation (INFL) were the major monetary policy transmission mechanism predicting the level of economic growth in Nigeria. Likewise, the study identified interest rate (INTR) and deposit money banks credit to the private sector (BCR) as weak transmission variables driving economic growth and prices in Nigeria. The study concludes that the monetary policy transmission mechanisms have had a mixed bag in predicting economic growth in Nigeria. Based on available evidences, it seems that negative impacts outweighs the positives, especially, as the critical variables like interest rate, credit to the private sectors and exchange rate depreciation plays a key role in driving economic growth. This further buttressed by the negative and significant coefficient of RGDP growth rate within the study period. The reasons may not be unconnected with fiscal dominance, policy inconsistency, underdeveloped domestic productive capacity, multiple exchange rates and Nigeria's mono-product syndrome in the international market. The monetary authority should be religious in seeing through monetary policies, especially, in maintaining consistency. Devaluation or depreciation of the naira also is not pro-growth and should be jettisoned, until we are able to diversify our economy and achieve improvements in our domestic productive capacities. Evidently, access to private sector credit at a lower interest should be pursued vigorously.

\section{References}

Adeleke, A. I., Oboh, V.U and Shobande, O.A (2015). Monetary policy towards inclusive growth in Nigeria. The Nigerian journal of economic and social studies. 57(2): 313-337.

Bekhet, H. A. and Matar, A., 2013. Co-integration and causality analysis between stock market prices and their determinants in Jordan. Economic Modelling 35, 508-514.

Central Bank of Nigeria (2015). The conduct of monetary policy. Retrieved on 12/04/2018 from www.cenbank.org/documentpolicyreview.asp

Mengesha, L.G and Holmes, M.J (2013. Monetary policy and its transmission mechanisms in Eritrea. Journal of Policy modelling, 35(2013) 766-780.

Nenbee, S.G and Onuchukwu, O. (2017). Role of International Trade and Foreign Direct Investment in Nigeria's Industrialization. African Journal of Applied and Theoretical Economics, Special edition, p.p 100-118.

Nenbee, S. G and Krama, I. J (2017). Transmission Mechanism of monetary policy discourse: A search for growing Nigeria out of recession. African Journal of Applied and Theoretical Economics, Special edition, p.p 50-67.

Nteegah, A., Nelson, M and Owede, V.M. (2017). Trade liberalization and economic growth in Nigeria. International Journal of Social Science and Economics Invention (IJSSEI) Volume 03(01) 119-131.

Okwo, A.T., Obiakor, R.T., Falaiyu, O.B., and Owolabi, S.A. (2012). Empirical analysis of the effects of monetary policy innovations on stabilization of commodity prices in Nigeria. European journal of economics, finance and administrative sciences, 7(2) 64-79.

Onyekwere, T.V., and Nwaeze, N.C. (2018). An assessment of the impact of monetary policy on the general 
performance of the economic. Unpublished B.sc thesis.

Pesaran, M., Shin, Y. and Smith, R., (2001). Bounds testing approaches to the analysis of level relationships. Journal of Applied Econometrics, 16, 289-326.

Nnmadi C. Nwaeze, Ph.D. was born in Aba, Abia State, Nigeria. He holds three Degrees in Economics, including a Ph. D in development economics from the prestigious University of Port Harcourt, Nigeria, in 2017. His research interest is in quantitative and development studies. He has to his credit more than twenty (20) peer reviewed journals and three text books (in development, political economy and inferential statistics). He has had a meritorious banking career spanning over ten (10) years, before returning as an academic. Presently, he is a Lecturer in the Department of Economics, Abia State University, Uturu, Abia State Nigeria. 